\title{
Chemical Composition, Antimicrobial Activity and Potential Cytotoxic Effect of Mentha viridis (Spearmint) Extracts from Saudi Arabia
}

\author{
NADA M. ALI \\ Department of Chemistry, Science college, Albaha University, Albaha, Saudi Arabia. \\ ${ }^{*}$ Corresponding author E-mails: nada.m@ bu.edu.sa \\ http://dx.doi.org/10.13005/ojc/370116
}

(Received: December 15, 2020; Accepted: February 07, 2021)

\begin{abstract}
Many medicinal plants have been used to treat and prevent illnesses in Saudi Arabia. The present study aimed to investigate the chemical composition of Mentha viridis obtained from Albaha region of Saudi Arabia and evaluate its antimicrobial and antiproliferative potential. The extract was obtained from plant fresh material and identified by gas chromatography-mass spectrometry (GC-MS). The antimicrobial and antiproliferative potential of the plant extract was analysed by performing four subsequent extracts: ethanol, petroleum ether, chloroform, and methanol. The GC-MS analysis showed carvone as a main component, as it comprised $64.82 \%$ of the plant extract. In antimicrobial activity, methanol extract showed significant activity against Pseudomonas aeruginosa with zone of inhibition of $15 \mathrm{~mm}$. The MTT assay showed that petroleum ether and chloroform extracts have moderate cytotoxic effect against MCF-7 breast cancer cell line with $\mathrm{IC}_{50}$ values of $193.23 \mu \mathrm{g} / \mathrm{mL}$ and $131.86 \mu \mathrm{g} / \mathrm{mL}$, respectively. Chloroform extract also showed mild activity against HCT-116 colorectal cancer cell line with $\mathrm{IC}_{50}$ value of $189.2 \mu \mathrm{g} / \mathrm{mL}$. This study highlights the potential of $M$. viridis extracts as powerful bioactive phytochemicals with possible role in diseases and cancer therapy.
\end{abstract}

Keywords: Mentha viridis, antimicrobial, antiproliferative, Medicinal plant.

\section{INTRODUCTION}

Presently, the effectiveness, low cost, and fewer side effects have increased the worldwide demand of medicinal plants. Many pharmaceutical companies are engaged in large-scale pharmacologic screening of medicinal plants for developing new drugs $^{1}$. Medicinal plants are rich resources of traditional medicines and many modern medicines, including aspirin, digoxin, quinine and morphine are obtained from willow bark foxglove, cinchona bark, opium poppy, respectively ${ }^{2}$. The effectiveness of medicinal plants has been proved on individual body systems, for example, they have profound antioxidant, anti-inflammatory, antimicrobial and immunostimulatory properties ${ }^{1}$.

Mentha species is a member of the Lamiaceae (Labiatae) family and are mass distributed across all continents ${ }^{3,4}$. According to latest data,

This is an Open Access article licensed under a Creative Commons license: Attribution 4.0 International (CC- BY). Published by Oriental Scientific Publishing Company @ 2018 
Lamiaceae family is considered one of the largest families of plants that produce flowers with around 4000 species that grow worldwide ${ }^{5}$ and is considered to have the highest number of medicinal plants ${ }^{6}$. The use of Mentha plants in treating many diseases, including common cold, fever, throat infection, bronchitis, ulcerative colitis, and digestive issues has been known for a long time ${ }^{7,8}$. Moreover, its use as an antimicrobial, antioxidant, anti-motion sickness, anti-inflammatory and anticarcinogenic agent has also been reported.9-11

Mentha viridis, commonly known as spearmint, has well known industrial importance. The leaves of the $M$. viridis are used as flavouring agent in culinary purposes including iced drinks and jellies ${ }^{12}$.

The medicinal uses of $M$. virids are also well documented. It is considered as a relaxant, antispasmodic, and soothing agent in nausea and vomiting ${ }^{13}$. Moreover, it is widely known as a strong stimulant and carminative ${ }^{14}$. M. viridis extract contains various terpenes, fatty acid esters and Vitamin E, which explains its antioxidant potential ${ }^{15}$. The essential oil from leaves of $M$. viridis has potent antimicrobial activity ${ }^{16}$.

Previously, no study has been reported on M. viridis cultivated in Albaha region. Its medicinal properties and safe usage have made it an ideal option for studying. In addition, plants growing in different geographical and weather conditions tend to have different phytochemical composition and different biological activities. This study aims to characterize the bioactive compounds of $M$. viridis from Albaha region and investigate its extracts for antimicrobial and antiproliferative potential.

\section{METHODS}

\section{Plant materials}

The plant was obtained from local farmer market in Albaha region, Saudi Arabia in March 2019. Dr. Haider authenticated its botanical identification. An authenticated specimen was deposited at the Botany Laboratory, Department of Biology, Albaha University.

\section{Preparation of samples for GC-MS analysis}

The leaves and stem (representing fresh aerial parts of the plant), with a weight of $25 \mathrm{~g}$, was transferred to $15-\mathrm{mL}$ screw test tube, mixed with $5 \mathrm{~mL}$ methanol, capped, vortexed for $5 \mathrm{~min}$, sonicated for $30 \mathrm{~min}$, mixed with about $2 \mathrm{~g}$ anhydrous sodium sulfate, filtered through a filtration disc of the PTFE syringe, 0.22 micron thickness. The produced filtrate is then concentrated to $1 \mathrm{~mL}$ using room temperature Nitrogen gas in the form of a gentle stream. The extract contains both polar and nonpolar components of the plant material. A portion from the clear extract was transferred to autosampler vial. GC-MS analysis sample was prepared by injecting $1.5 \mu \mathrm{l}$ into the vial.

\section{The GC-MS analysis}

The GC-MS analysis of bioactive compounds from plants extract was done using Clarus 500 GC-MS (Perkin Elmer, Shelton, CT, USA). TurboMass version 5.4.2.1617 was used as a software integrator \& controller. An Optima $\AA 1$ GC capillary column, Crossbond $\circledast 100 \%$ dimethyl polysiloxane (30-meter $\times 0.25 \mathrm{~mm}$ ID $\times 0.25 \mu \mathrm{m}$ df), Macherey-Nagel, GMBH, Duren, Germany) was used. Al Hashmi et al.,(2013) described a similar setting, but a few modifications were made. In this assay, Helium (purity 99.9999\%) was used as a carrier gas, with $0.90 \mathrm{~mL} / \mathrm{min}$ flow rate. Source $(\mathrm{El}+)$ : source was set to $215^{\circ} \mathrm{C}$ temperature, GC inlet line was set to $265^{\circ} \mathrm{C}$ temperature, with $70 \mathrm{eV}$ Electron energy, and $100 \mathrm{~V}$ trap-emission. The oven programming went as follows: $50^{\circ} \mathrm{C}$ temperature initially (with a $5 \mathrm{~min}$ hold), then raised to $260^{\circ} \mathrm{C}$ (at a rate of $10^{\circ} \mathrm{C} / \mathrm{min}$, with $5 \mathrm{~min}$ hold), then raised again to $280^{\circ} \mathrm{C}$ (at a rate of $10^{\circ} \mathrm{C} / \mathrm{min}$, with $2 \mathrm{~min}$ hold). Temperature of the injector was set to $265^{\circ} \mathrm{C}$, $1.0 \mu \mathrm{L}$ was injected, and a 50:1 ratio was used for splitting. A total MS scan from 40 to $500 \mathrm{~m} / \mathrm{z}(500$ $\mathrm{scan} / \mathrm{sec}$ ) was applied to acquire the sample. The eluted compounds were characterized using NIST 2008, as reported in Mosbah et al.,(2018).

\section{Extraction of crude extracts}

The leaves and stem (representing fresh aerial parts of the plant) were air dried at room temperature $\left(25 \pm 2^{\circ} \mathrm{C}\right)$ for about 7 days. The dried material was ground using an electric blender machine (Pulverizer HR-30B, USA). $200 \mathrm{~g}$ powder material was macerated in $600 \mathrm{~mL}$ methanol with shaking for 3 days. Then they were filtered through Whatman no1 filter paper. The residue was further extracted two times by using the same fresh solvent. All filtrates were compiled for further evaporating. The 
resulting residue was air dried and further extracted with solvents of increasing polarity namely petroleum ether, chloroform, and ethanol by using similar procedure carried out for the methanol extraction. Finally, rotary evaporator (IKA RV-10, Germany) was used under reduced pressure and low temperature to evaporate solvent from each filtrate extract until dryness was achieved. ${ }^{19}$

\section{Antimicrobial evaluation}

The antimicrobial activity of the four plant extracts (methanol, ethanol, petroleum ether, and chloroform) was tested against standard strains of four bacteria and one fungus. King Abdulaziz University Hospital, Jeddah, KSA provided the organisms through their microbiology laboratory. These strains were: Staphylococcus aureus (reference: ATCC 29213) and Bacillus subtilis (Reference: ATCC 6633), both Gram-positive bacteria, as well as Escherichia coli (Reference: ATCC 35218) and Pseudomonas aeruginosa (Reference: ATCC 27853), both Gram-negative bacteria and finally fungus: Candida albicans (Reference: ATCC 76615).

Agar diffusion technique was used for the initial screening of the antibacterial and antifungal activities, as previously described (20). Briefly, MullerHinton agar $(25 \mathrm{~mL})$ containing $1 \mathrm{~mL}$ bacterial culture $\left(1 \times 10^{6} \mathrm{CFU} / \mathrm{mL}\right)$ was used to fill Petri dishes with a capacity of $90 \mathrm{~mm}$. The strains were inoculated separately. Seven holes (4 $\mathrm{mm}$ in diameter) were prepared in the seeded agar dishes, which were then filled with $50 \mu \mathrm{L}$ of each extract $(10 \mathrm{mg} / \mathrm{mL})$, as well as a negative control agent (10\% dimethyl sulfoxide (DMSO)). Dishes were then incubated at $37^{\circ} \mathrm{C}$ for 24 hours. Success of the Inhibitory activity was marked by the absence of bacterial growth in the area surrounding the holes. Triplicates were carried out against each of the tested microorganisms. The growth inhibition zones' diameters were measured using a calliper and averaged at the end of the incubation period. The mean values were tabulated.

\section{Acquisition of cell lines and culture medium preparation}

Human breast cancer MCF-7 and colorectal cancer HCT-116 cell lines were obtained from Dr. Thikryat Neamatallah, Pharmacology and Toxicology laboratory, Faculty of medicine, King Abdulaziz University, Jeddah, KSA. Dulbecco's Modified Eagles
Medium (DMEM)/high glucose medium was used as a culture medium, augmented with $10 \%$ fetal bovine serum (FBS), as well as 10,000 units/mL penicillin/ streptomycin (Pen/Strep) and 1\% glutamine). All reagents were purchased from Thermo Fisher (Thermo Fisher Scientific UK Ltd, Leicestershire, UK) except Pen/Strep, which was obtained from Sigma (Sigma-Aldrich, St. Louis, MO, USA). The cell lines were cultured in $75 \mathrm{~cm}^{2}$ flasks were used to culture the cells, and were sustained at $37^{\circ} \mathrm{C}$ in a $5 \%$ $\mathrm{CO}_{2}$ humid incubator. A Class II Safety Flow Hood was used to carry out the cell culture procedure, under aseptic conditions.

\section{MTT assay}

Both types of cells were seeded at $\left(1 \times 10^{5}\right.$ cells $/ \mathrm{mL}$ ) into a plate containing 96 wells, together with 3 duplicates. The whole assay was incubated at $37^{\circ} \mathrm{C}$ through the night for attachment in a humid atmosphere containing $5 \% \mathrm{CO}_{2}$ as described by Mansour et al.,(2016), but slightly modified. In this assay, plant extracts (methanol, ethanol, petroleum ether, and chloroform) at 7 serial dilutions (1000$10 \mu \mathrm{g} / \mathrm{mL}$ ) were introduced in 3 identical settings (triplicates) and incubated for $72 \mathrm{~h}$, at a temperature of $37^{\circ} \mathrm{C}$, and $5 \% \mathrm{CO}_{2} .0 .1 \%$ DMSO was used as a vehicle to dissolve the drugs in. Untreated cells were used as control. Afterwards, $100 \mu \mathrm{L}$ of full medium containing $10 \%$ of 3-(4,5- dimethylthiaxolyl2)-2,5-diphenyltetrazolium bromide (MTT) (10 mg/ $\mathrm{mL}$ ) was used as replacements for each well at each recorded time point. Cells were incubated again at a temperature of $37^{\circ} \mathrm{C}$, and $5 \% \mathrm{CO}_{2}$ for 4 hours. $100 \mu \mathrm{L}$ of DMSO was added after removing the media, and incubation at a temperature of $37^{\circ} \mathrm{C}$, and $5 \% \mathrm{CO}_{2}$ was done for an additional 5 minutes. Spectra Max M3 plate reader at $570 \mathrm{~nm}$ was used to quantify the plates.

The following formula was used to determine the viability percentage:

Cell viability $(\%)=(\mathrm{A}$ of treated cells $/ \mathrm{A}$ of control cells) $\times 100$.

\section{Statistical analysis}

Triplicates of three independent experiments were carried out and data are expressed as the mean $\pm \mathrm{SD} . \mathrm{IC}_{50}$ value was calculated by ED50 GraphPad Prism software (GraphPad Prism 5.0, GraphPad Software, Inc., CA, USA). 


\section{RESULTS}

\section{GC-MS Analysis}

Th analysis showed that aerial parts (stem and leaves) of $M$. viridis methanolic extract had a variety of phytochemicals, which are shown in the GC-MS chromatograms (Fig. 1). Thirty-two distinct phytochemical compounds were present in $M$. viridis methanolic extract in different ratio and accounted

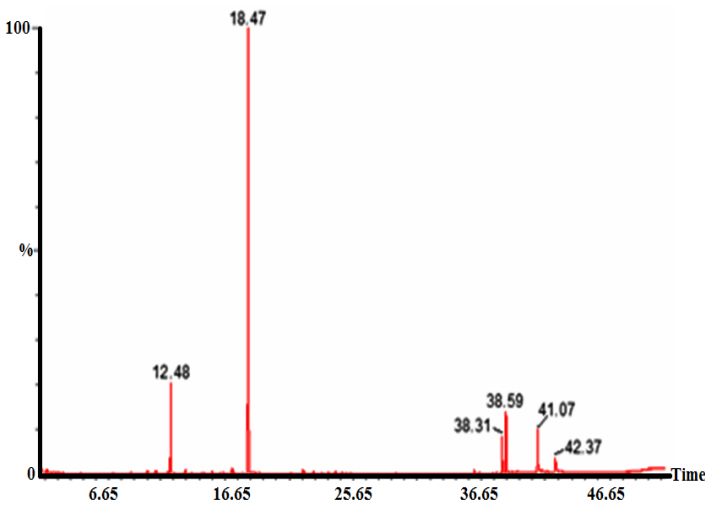

Fig. 1. Gas chromatography-mass spectrometry chromatogram of Mentha viridis methanolic extract. The chromatogram shows various phytocomponents peaks separated at different retention times for $98.6 \%$ of the total components. It was found that carvone was the most abundant phytochemical, as it was present in $64.82 \%$ followed by eucalyptol $(10.44 \%)$, oleamide $(6.34 \%)$ and phytol $(5.40 \%)$.

Table 1 shows the identified components in $M$. viridis methanolic extract. Fig. 2 illustrates the chemical structure of some active components detected in $M$. viridis methanolic extract.
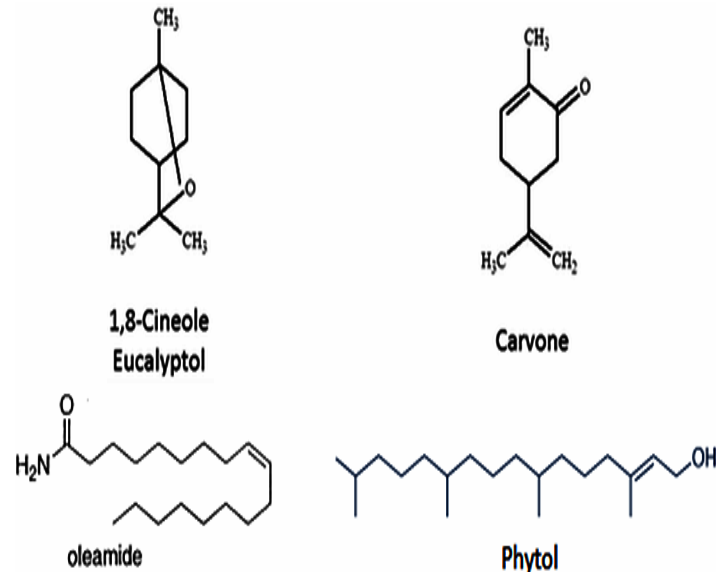

Fig. 2. Chemical structures of some bioactive constituents of Mentha viridis extract

Table 1: Chemical composition of Mentha viridis methanolic extract

\begin{tabular}{|c|c|c|c|c|}
\hline Peak number & Rt, mina & Component & Area & $\%$ Area \\
\hline 1 & 7.99 & 2,5-Diethyltetrahydrofuran & 267132 & 0.13 \\
\hline 2 & 9.36 & 1R- $\alpha$-Pinene & 298463 & 0.14 \\
\hline 3 & 10.62 & $\beta$-Thujene & 407800 & 0.20 \\
\hline 4 & 10.72 & $\beta$-Pinene & 574268 & 0.28 \\
\hline 5 & 11.27 & Myrcene & 498542 & 0.24 \\
\hline 6 & 11.41 & n-Octan-3-ol & 751261 & 0.36 \\
\hline 7 & 12.22 & Benzeneacetaldehyde & 565544 & 0.27 \\
\hline 8 & 12.48 & Eucalyptol (1,8-Cineole) & 19610798 & 10.44 \\
\hline 9 & 13.64 & (E)-Sabinene hydrate & 988349 & 0.48 \\
\hline 10 & 14.03 & Fenchone & 72673 & 0.03 \\
\hline 11 & 15.62 & (-)-Camphor & 400971 & 0.19 \\
\hline 12 & 16.29 & 3-Methyl-1,2-cyclopentanedione & 44459 & 0.02 \\
\hline 13 & 16.49 & Myrcenol & 44459 & 0.02 \\
\hline 14 & 16.54 & Borneol & 489790 & 0.24 \\
\hline 15 & 17.15 & Dihydrocarvone & 368367 & 0.18 \\
\hline 16 & 17.36 & Neodihydrocarveol & 152889 & 0.07 \\
\hline 17 & 18.02 & cis-Carveol & 200112 & 0.10 \\
\hline 18 & 18.47 & Carvone & 130497712 & 64.82 \\
\hline 19 & 19.28 & cis-Carvone oxide & 117097 & 0.06 \\
\hline 20 & 22.72 & $\beta$-Bourbonene & 594923 & 0.29 \\
\hline 21 & 22.86 & $\beta$-Elemene & 317625 & 0.15 \\
\hline 22 & 23.57 & Caryophyllene & 583306 & 0.28 \\
\hline 23 & 24.71 & (+)-Epi-bicyclosesquiphellandrene & 355040 & 0.17 \\
\hline 24 & 25.28 & Germacrene D & 459971 & 0.22 \\
\hline 25 & 25.81 & 1,5-Heptadiene, 2,5-dimethyl-3-methylene- & 203301 & 0.10 \\
\hline 26 & 30.00 & Copaene & 78219 & 0.04 \\
\hline 27 & 31.03 & $\alpha$-Cadinol & 53101 & 0.03 \\
\hline 28 & 36.14 & Tridecanoic acid, methyl ester & 520004 & 0.25 \\
\hline 29 & 38.31 & Linolenic acid, methyl ester & 6695976 & 3.22 \\
\hline 30 & 38.59 & Phytol & 11224343 & 5.40 \\
\hline 31 & 41.07 & Oleamide & 13174507 & 6.34 \\
\hline 32 & 42.37 & $\begin{array}{c}\text { Limonen-6-ol, pivalate } \\
\text { Total }\end{array}$ & 8055191 & $\begin{array}{c}3.88 \\
98.64\end{array}$ \\
\hline
\end{tabular}

${ }^{\text {aRetention time (as minutes) }}$

${ }^{\mathrm{b}}$ Compounds listed in order of elution from a column 


\section{Antimicrobial Activities}

The In vitro antifungal and antibacterial bioassays were carried out using the extracts from $M$. viridis. A variety of bacteria (both Grampositive and Gram-negative) as well as fungal strains were used as test strains and agar diffusion assays were carried out to analyse the antimicrobial properties of $M$. viridis. The results were determined on the basis of formation of zones of inhibition (measured in $\mathrm{mm}$ ) around the extract on the agar plates which were seeded with test microbial strains. The methanolic extract showed significant antibacterial activity against $P$. aeruginosa with zone of inhibition of $15 \mathrm{~mm}$ while ethanol, chloroform and petroleum ether extracts did not show any antimicrobial activity against the tested microorganisms. The results are given in Table 2.

Table 2: Antibacterial and antifungal activities of Mentha viridis extracts

\begin{tabular}{|c|c|c|c|c|c|}
\hline \multirow[t]{3}{*}{ Extracts } & \multicolumn{5}{|c|}{ Zone diameter (mm) } \\
\hline & \multirow{2}{*}{$\begin{array}{l}\text { Gram-positive bacteria } \\
\text { Staphylococcus aureus }\end{array}$} & \multicolumn{3}{|c|}{ Gram-negative bacteria } & \multirow{2}{*}{$\begin{array}{c}\text { Fungus } \\
\text { Candida albicans }\end{array}$} \\
\hline & & Bacillus subtilis & Escherichia coli & Pseudomonas aeruginosa & \\
\hline Chloroform & - & - & - & - & - \\
\hline Methanol & - & - & - & $15 \pm 0.04$ & - \\
\hline Ethanol & - & - & - & - & - \\
\hline Petroleum ether & - & - & - & - & - \\
\hline
\end{tabular}

The diameters of the inhibition zones. Values are the means \pm SD of three cultures.

\section{MTT (IC $\left.{ }_{50}\right)$ Assay}

The antiproliferative effect of the extract of $M$. viridis on human cells' viability was analysed using MTT assay. Two cancer cell lines, human breast cancer (MCF-7) and colorectal cancer (HCT116) cell lines were selected and tested against $M$. viridis extracts. Readings were taken using spectrophotometer Spectra Max M3 and are given in Table 3. Petroleum ether and chloroform extracts showed moderate cytotoxic effects against MCF-7 with $\mathrm{IC}_{50}$ values $193.23 \mu \mathrm{g} / \mathrm{mL}$ and $131.86 \mu \mathrm{g} / \mathrm{mL}$, respectively. Chloroform extract also showed mild activity against HCT-116 with $\mathrm{IC}_{50}$ value of 189.2 $\mu \mathrm{g} / \mathrm{mL}$. Ethanol and methanol extracts showed $\mathrm{IC}_{50}$ higher than $200 \mu \mathrm{g} / \mathrm{mL}$ against the tested cell lines, which is indicative of no cytotoxicity.

Table 3: The $\mathrm{IC}_{50}$ of Mentha viridis extracts against tested human cancer cell lines

\begin{tabular}{lcc}
\hline Compound & $\mathrm{IC}_{50}{ }^{*}(\mu \mathrm{g} / \mathrm{mL}) \mathrm{MCF}-7$ & $\mathrm{IC}_{50}{ }^{*}(\mu \mathrm{g} / \mathrm{mL}) \mathrm{HCT}-116$ \\
\hline $\begin{array}{l}\text { Standard drug } \\
\text { (paclitaxel) }\end{array}$ & $0.23 \pm 2.2 \pm 10^{-6}$ & $0.32 \pm 5.7 \pm 10^{-6}$ \\
$\begin{array}{l}\text { Chloroform extract } \\
\text { Petroleum ether }\end{array}$ & $131.86 \pm 4.2 \times 10^{-5}$ & $189.2 \pm 1.13 \times 10^{-4}$ \\
extract & $>200$ & $>200$ \\
Ethanol extract & $>200$ & $>200$ \\
Methanol extract & & $>200$ \\
\hline
\end{tabular}

* $\mathrm{IC}_{50}$ is the half maximal inhibitory concentration $(\mu \mathrm{g} / \mathrm{mL})$. Values are the means \pm SD of three cultures.

\section{DISCUSSION}

Various types of infectious bacteria and cancers are a constant threat for human health and are the leading cause of morbidity and mortality worldwide. This continuous risk calls for the need of exploring and finding new cost-effective therapies with better effectiveness. Medicinal plants have proved to be a significant source of novel therapeutic substances. Today, various plant-derived potent chemicals are being extensively used and studied for human therapeutic purposes. The present study aimed to analyse the phytochemical contents of $M$. viridis extract and evaluate its antimicrobial and anticancer properties.

\section{GC-MS Analysis}

The methanolic extract of different parts of $M$. viridis were subjected to GC-MS analysis to determine its complete phytochemical composition and to determine the ratio of each component in the respective plants. The peaks in the GC-MS chromatogram showed that about thirty distinct phytochemicals were present in the $M$. viridis extract. The most abundant component was carvone which has the highest ratio, i.e., $64.82 \%$. Few other components were present in high quantities, including eucalyptol (1,8-cineole) (10.44\%), oleamide (6.34\%) and phytol (5.40\%). Various studies have reported carvone as the most abundant component of M. viridis ${ }^{22}$. For example, according to the findings of Verma et al., (2010), the analysis of $M$. viridis sample collected from India (specifically from the mid-hills of Himalayan region) at different stages of crop 
growth showed that carvone is the most prevalent phytochemical with percentages ranging between of $59.6-72.4 \%$ in different stages of sampling. Moreover, phytochemical analysis of $M$. viridis collected from farms in Al-Kadaro region of Sudan showed carvone $(64.63 \%)$ as a major component ${ }^{16}$. Furthermore, another study reported that carvone (50.47\%) followed by 1,8 -cineole $(9.14 \%)$, limonene $(4.87 \%)$, camphor $(3.68 \%)$, and $\beta$-caryophyllene $(3 \%)$ were the key component of Tunisian $M$. viridis ${ }^{23}$.

GC-MS profiling of our study also indicated the presence of fatty acid methyl esters (tridecanoic acid, linolenic acid) terpenoids and terpenoid alcohol (eucalyptol, phytol). Most of the plant terpenoids and their derivatives are biologically active and are used extensively as traditional herbal remedies for many diseases ${ }^{24}$. They are also used worldwide in food, cosmetics and pharmaceutical industries ${ }^{25}$.

\section{Antimicrobial Activities}

The significant antimicrobial activity was only shown by methanol extract whose concentration was $10 \mathrm{mg} / \mathrm{mL}$, forming an inhibition zone as of 15 $\mathrm{mm}$ when interacting with $P$. aeruginosa. However, no antimicrobial activity was noted by other extracts (10 $\mathrm{mg} / \mathrm{mL}$ ) obtained from $M$. viridis against the tested microorganisms. The results are similar to those by Mkaddem et al., (2009) who stated that no antimicrobial activity of essential oil extract $(15 \mu \mathrm{l} /$ $\mathrm{mL}$ ) from Tunisian $M$. viridis was observed against E. coli and S. aureus. Referring to Silva et al., (2015), the essential oil from $M$. viridis showed antimicrobial activity against $E$. coli (a Gram-ve bacterium) and S.aureus (a Gram+ve bacterium) forming zones of inhibition of $6 \mathrm{~mm}$ and $8 \mathrm{~mm}$, respectively, when the minimal inhibitory concentration (MIC) was $62.5 \mu \mathrm{l} / \mathrm{mL}$. Other study showed that MIC of 12.5 $\mathrm{mg} / \mathrm{mL}$ is the lowest concentration at which all the tested microorganisms are inhibited ${ }^{16}$. Our study found different results, which may be associated with differences in the concentration of essential oil and crude extracts of $M$. viridis used against the tested microorganisms. In addition, the disagreement was probably due to the difference in amounts and the nature of the components that presented in the essential oil and crude extracts of $M$. viridis, because Silva et al.,(2015) found linalool (40.70\%), carvone (13.52\%) and $\alpha$-terpinene $(8.56 \%)$ as the chief components.

\section{MTT (IC s0 $_{\text {The }}$ Assay}

The antiproliferative effects of $M$. viridis extracts $(10 \mu \mathrm{g} / \mathrm{mL})$ on human breast cancer (MCF-7) and colorectal cancer (HCT-116) cell lines, were analysed using the MTT $\left(\mathrm{IC}_{50}\right)$ assay. Chloroform extract showed moderate antiproliferative activity and had $\mathrm{IC}_{50}(\mu \mathrm{g} / \mathrm{mL})$ values less than 200 against both the MCF-7 and HCT-116 cell lines. Petroleum ether extract showed inhibition effect only against MCF-7 with $\mathrm{IC}_{50}$ values $193.23 \mu \mathrm{g} / \mathrm{mL}$. However, no cytotoxic activity was observed in methanol and ethanol extracts against the tested cell lines. Sharma et al.,(2014), evaluated the anticancer potential of methanolic and aqueous extracts of whole plant of M. viridis against MCF-7 and HCT-116 In vitro, using a $100 \mu \mathrm{g} / \mathrm{mL}$ concentration, and sulforhodamine Blue (SRB) assay. Methanolic extract exhibited cytotoxicity against MCF-7 while aqueous extract was found active against HCT-116 27 . Our study found different results, which can be attributed to the difference in doses concentration applied against the tested cancer cell lines.

In this study, it is noticed that the nonpolar solvents (petroleum ether and chloroform) used for the plant extraction exhibited more cytotoxic effects against tested cancer cells. These effects are most likely due to the presence of more bioactive terpenoids and sesquiterpenes in these solvents. It has been reported that carvone and its derivatives do not exhibit cytotoxic effects against cancer cells ${ }^{28}$ while many of the plant terpenoids inhibit different human cancer cells and are used as anticancer drugs ${ }^{25,29,30}$.

From the current findings we can safely conclude that extracts from $M$. viridis can be ideal candidates for novel therapeutic research. The difference observed in the antibacterial and antiproliferative properties of M.viridis between our results and other reported findings is certainly due to the chemical composition, methods used, strains tested, dose concentrations applied, growing conditions and regions. The emergence of novel infectious diseases and development of bacteria resistance against the available antibiotics have made it inevitable that medicinal plants, especially from novel environments, should be explored for their therapeutic potentials. The present study is among the very first studies that have investigated and explored the M. viridis species of Albaha Region, 
KSA, and it highlights the need and importance of similar studies.

\section{ACKNOWLEDGEMENT}

The principal investigator of this study gratefully acknowledges the Deanship of Scientific Research, Albaha University, Albaha, KSA for supporting by grant \#17-1439.

\section{Conflict of Interest}

There are no conflicts of interest to declare.

\section{REFERENCES}

1. Dar RA.; Shahnawaz M.; Qazi PH. General overview of medicinal plants: A review. J Phytopharm., 2017, 6(6), 349-51.

2. Dias DA.; Urban S.; Roessner U. A historical overview of natural products in drug discovery. Metabolites., 2012, 2(2), 303-36.

3. Salehi B.; Stojanovic-Radic Z.; Matejic J.; Sharopov F.; Antolak H.; Kregiel D.; Plants of genus Mentha: From farm to food factory. Plants., 2018, 7(3), 70.

4. Mamadalieva NZ.; Akramov DK.; Ovidi E.; Tiezzi A.; Nahar L.; Azimova SS.; Aromatic medicinal plants of the Lamiaceae family from Uzbekistan: ethnopharmacology, essential oils composition, and biological activities. Medicines., 2017, 4(1), 8.

5. Sadeghi Z.; Akaberi M.; Valizadeh J. Otostegia persica (Lamiaceae): A review on its ethnopharmacology, phytochemistry, and pharmacology. Avicenna J phytomedicine., 2014, 4(2), 79.

6. Ouakouak H.; Chohra M.; Denane M. Chemical composition, antioxidant activities of the essential oil of Mentha pulegium L, South East of Algeria. Int Lett Nat Sci., 2015, 39.

7. Eissa TAF.; Palomino OM.; Carretero ME.; Gómez-Serranillos MP. Ethnopharmacological study of medicinal plants used in the treatment of CNS disorders in Sinai Peninsula, Egypt. $J$ Ethnopharmacol., 2014, 151(1), 317-32.

8. Darwish RM.; Aburjai TA. Effect of ethnomedicinal plants used in folklore medicine in Jordan as antibiotic resistant inhibitors on Escherichia coli. BMC Complement Altern Med., 2010, 10(1), 9.

9. Benzaid C.; Tichati L.; Djeribi R.; Rouabhia M. Evaluation of the Chemical Composition, the Antioxidant and Antimicrobial Activities of Menthax piperita Essential Oil against Microbial Growth and Biofilm Formation. J Essent Oil Bear Plants., 2019, 22(2), 335-46.

10. Shaikh S.; Yaacob H Bin.; Rahim ZHA. Prospective role in treatment of major illnesses and potential benefits as a safe insecticide and natural food preservative of mint (Mentha spp.): a Review. Asian J Biomed Pharm Sci., 2014, 4, 1-12.

11. Jain D.; Pathak N.; Khan S.; Raghuram GV.; Bhargava A, Samarth R, Evaluation of cytotoxicity and anticarcinogenic potential of Mentha leaf extracts. Int J Toxicol., 2011, 30(2), 225-36.

12. Verma RS.; Padalia RC.; Chauhan A. Chemical profiling of Mentha spicata L. var. 'viridis' and Mentha citrata L. cultivars at different stages from the Kumaon region of western Himalaya. Med Arom Plant Sci Biotechnol., 2010, 4, 73-6.

13. Aziz MM.; Saqib NU.; Akhtar N.; Asif HM, Jamshaid M, Sultana S, Phytochemical screening and evaluation of the diuretic activity of aqueous methanol extract from aerial parts of mentha viridis linn (labiatae) in albino rats. Trop J Pharm Res., 2014, 13(7), 1121-5.

14. Grieve M. A modern herbal. Courier Corporation., 2013, 2.

15. A Hassan H.; S Kabbashi A.; Abedallah A.; D Wagh V.; Abdalla Ahmed Hamdi O. Chemical Composition, Antioxidant Activity and Cytotoxicity of Essential Oil of Mentha viridis. Acta Sci Med Sci., 2019, 3(8), 200-5.

16. Balla OY.; Ali MM.; Garbi MI.; Kabbashi AS. Chemical composition and antimicrobial activity of essential oil of Mentha viridis. Biochem Mol Biol., 2017, 2(5), 60-6.

17. Al Hashmi LS.; Hossain MA.; Weli AM, AlRiyami Q.; AISabahi JN. Gas chromatographymass spectrometry analysis of different organic crude extracts from the local medicinal plant of Thymus vulgaris L. Asian Pac J Trop Biomed., 2013, 3(1), 69-73.

18. Mosbah H.; Louati H.; Boujbiha MA.; Chahdoura H.; Snoussi M.; Flamini G, Phytochemical characterization, antioxidant, antimicrobial and pharmacological activities of Feijoa sellowiana leaves growing in Tunisia. Ind Crops Prod., 2018, 112, 521-31. 
19. Jeyaseelan EC.; Jenothiny S.; Pathmanathan MK.; Jeyadevan JP. Antibacterial activity of sequentially extracted organic solvent extracts of fruits, flowers and leaves of Lawsonia inermis L. from Jaffna. Asian Pac J Trop Biomed., 2012, 2(10), 798-802.

20. Kizil S.; Hasimi N.; Tolan V.; Kilinc E.; Yuksel U. Mineral content, essential oil components and biological activity of two mentha species $(M$. piperita L., M. spicata L.). Turkish J F Crop., 2010, 15(2), 148-53.

21. Mansour R Ben.; Jilani IBH.; Bouaziz M.; Gargouri B.; Elloumi N.; Attia H.; Phenolic contents and antioxidant activity of ethanolic extract of Capparis spinosa. Cytotechnology., 2016, 68(1), 135-42.

22. Bouyahya A.; Lagrouh F.; El Omari N.; Bourais I.; El Jemli M.; Marmouzi I.; Essential oils of Mentha viridis rich phenolic compounds show important antioxidant, antidiabetic, dermatoprotective, antidermatophyte and antibacterial properties. Biocatal Agric Biotechnol., 2020, 23, 101471.

23. Mkaddem M.; Bouajila J.; Ennajar M.; Lebrihi A.; Mathieu F.; Romdhane M. Chemical composition and antimicrobial and antioxidant activities of Mentha (longifolia L. and viridis) Essential oils. J Food Sci., 2009, 74(7), M358-63.
24. Yadav N.; Yadav R.; Goyal A. Chemistry of terpenoids. Int J Pharm Sci Rev Res., 2014, 27(2), 272-8.

25. Perveen S, Al-Taweel A. Introductory chapter: terpenes and terpenoids. Terpenes and Terpenoids., 2018, 1-12.

26. Silva LF.; das Graças Cardoso M, Batista LR, de Souza Gomes M, Rodrigues LMA, Rezende DA de CS, et al. Chemical characterization, antibacterial and antioxidant activities of essential oils of Mentha viridis L. and Mentha pulegium L.(L). Am J Plant Sci., 2015, 6(05), 666.

27. Sharma V.; Hussain S.; Gupta M.; Saxena AK. In vitro anticancer activity of extracts of Mentha spp. against human cancer cells. Indian J Biochem. Biophys., 2014.

28. Moro IJ.; Gondo GDGA.; Pierri EG.; Pietro RCLR.; Soares CP.; Sousa DP de.; Evaluation of antimicrobial, cytotoxic and chemopreventive activities of carvone and its derivatives. Brazilian Journal of Pharmaceutical Sciences. scielo., 2017, 53.

29. Prakash V.Terpenoids as cytotoxic compounds: A perspective. Pharmacogn Rev., 2018, 12(24).

30. Sánchez M.; Mazzuca M.; Veloso MJ.; Fernández LR.; Siless G.; Puricelli L.; Cytotoxic terpenoids from Nardophyllum bryoides. Phytochemistry., 2010, 71(11-12), 1395-9. 